\title{
ELECTROCHEMICAL CORROSION OF MAGNESIUM ALLOY AZ31 WITH ADDITIVE LITHIUM
}

The purpose of performed tests was evaluation of resistance to electrochemical corrosion of extruded magnesium alloy AZ31 with additive of $4.5 \%$ Li. Corrosion tests were performed in 0.01-2.0 M NaCl solutions. Potentiodynamic tests enabled to register polarisation curves. With application of stereoscopic microscope Nikon SMZ745T and electron scanning microscope Hitachi S-4200, the surface of the alloy was observed after immersion tests performed in 1-6 days. Results of performed tests prove explicitly deterioration of corrosion properties of the alloy with the increase of molar concentration of $\mathrm{NaCl}$ solution. It can be seen that corrosion process is intensive and that intensity increases with the increase of solution concentration and extension of exposure time.

Keywords: magnesium alloy AZ31 with additive of $4.5 \% \mathrm{Li}$, electrochemical corrosion in $\mathrm{NaCl}$, potentiodynamic test, immersion test, SEM

\section{Introduction}

Advance in aircraft and automobile industries is connected with development of construction materials featuring lower density, higher strength and resistance to high temperatures and environmental factors in comparison to previously used materials. This group of materials also includes magnesium alloys featuring the least density from amongst metallic construction materials, high specific strength, good castability, machining properties, weldability in controlled atmospheres, high capability of vibration damping. Limitations in application of magnesium alloys include flammability, high reactivity, low abrasion resistance, low impact resistance and high production costs [1-4].

Magnesium alloys used in automobile industry include mainly alloys that are obtained through casting. Research related to production of cast composite materials (containing among other things glassy carbon particles) must be highlighted [1,511]. Recent years have brought increased interest in magnesium alloys obtained by means of plastic working. Flat die forging and die forging, rolling, extrusion forging or press forming of sheets in heated dies can be distinguished among plastic working techniques. Severe plastic deformation methods are also introduced; they enable magnesium grain refining during treatment, which improves its formability. These methods include, among other things, equal channel angular pressing (ECAP), hydrostatic extrusion, KOBO extrusion [12-17].

The main factor hindering magnesium plastic forming is its low formability in ambient temperature, which is strictly related to hexagonal construction of crystal lattice of that element. Research aiming at improvement of magnesium alloys plasticity has led to development of ultra-light alloys containing lithium. Improvement of plasticity can be obtained by reduction of proportions of lattice constants c/a of hexagonal elementary cells of magnesium, which facilitates activation of additional slip planes. Thanks to that, a significant improvement of alloy formability can be obtained. Lithium additive brings about decrease of alloy mass and therefore - constructions made of it [18-20].

Application of magnesium alloys after plastic forming is to a great extend dependent on resistance to electrochemical corrosion. That issue has been the subject of intensive research for many years. Magnesium alloys corrosion mechanism is variable and depends on, among other things, alloy composition, crystallographic orientation, structural defects, microstructure or size of alloy grains. The environment in which the alloy is to work can also be a threat. Such environments as highly polluted air, medium containing salts or chlorides are regarded as aggressive. The reason for low corrosion resistance of magnesium is insufficient protective properties of the layer of oxides that is formed on the surface in oxidizing atmosphere or the layer of hydroxides in water solutions [21-32].

Alloying elements (including lithium as well) influence the change of corrosion properties of alloys. The purpose of the tests was to evaluate resistance to electrochemical corrosion of magnesium alloy $\mathrm{AZ3} 1$ with additive of $4.5 \% \mathrm{Li}$ in $\mathrm{NaCl}$ solutions.

\footnotetext{
SILESIAN UNIVERSITY OF TECHNOLOGY, FACULTY OF MATERIALS SCIENCE AND METALLURGY, POLAND

Corresponding author: eugeniusz.hadasik@polsl.pl
} 


\section{Material and methods}

Magnesium alloy AZ31 with additive of $4.5 \%$ Li after plastic forming in the form of longitudinal extrusion served as stock material for tests.

Resistance to electrochemical corrosion was evaluated on the ground of registered polarization curves with testing system VoltaLab PGP201 by Radiometer. Saturated calomel electrode (NEK) of KP-113 type served as reference electrode whereas platinum electrode of PtP-201 type served as auxiliary electrode. The tests started with determination of opening potential $E_{O C P}$. Next, polarisation curves were registered, starting the measurements with $E_{p o c z}=E_{O C P}-100 \mathrm{mV}$. Potential changed in anodic direction at a rate of $10 \mathrm{mV} / \mathrm{min}$. The tests were performed in solutions with the following concentration: $0.01,0.2,0.6,1.0$ and $2.0 \mathrm{M} \mathrm{NaCl}$. Temperature of the solution during the test was $21 \pm 1^{\circ} \mathrm{C}$. Registered curves enabled to determine typical properties describing resistance to pitting corrosion, i.e.: corrosion potential, polarisation resistance, corrosion current density.

Immersion tests were performed in solutions of concentration: $0.01,0.6$ and $2.0 \mathrm{M} \mathrm{NaCl}$. After grinding, samples were weighed and mass $\mathrm{m}_{0}$ was determined. After the alloy was subject to immersion in $\mathrm{NaCl}$ solution for $1 \div 6$ days, samples were taken out and corrosion products were removed. Next, they were washed with distilled water, degreased with acetone, dried and weighed again, determining mass $\mathrm{m}_{1}$. Performed tests enabled to determine corrosion rate $\mathrm{V}$. The surface of the alloy after immersion tests was observed with stereoscopic microscope Nikon SMZ745T and scanning microscope Hitachi S-4200.

\section{Results and discussion}

Potentiodynamic tests performed in solutions with concentration of $0.01-2.0 \mathrm{M} \mathrm{NaCl}$ enabled to determine corrosion properties of extruded magnesium alloy AZ31 with additive of $4.5 \% \mathrm{Li}$. Table 1 presents results of corrosion resistance test (mean measurement values).

TABLE 1

Results of electrochemical corrosion resistance tests of magnesium alloy $\mathrm{AZ3} 1+4.5 \% \mathrm{Li}$

\begin{tabular}{|c|c|c|c|}
\hline \hline Concentration NaCl, $\mathbf{M}$ & $\boldsymbol{E}_{\text {corr }}, \mathbf{m V}$ & $\boldsymbol{I}_{\text {corr. }} \mathbf{~} \mathbf{m A} / \mathbf{c m}^{\mathbf{2}}$ & $\boldsymbol{R}_{\boldsymbol{p}}, \mathbf{\Omega} \mathbf{c m}^{\mathbf{2}}$ \\
\hline 0.01 & -1438 & 0.023 & 1139 \\
\hline 0.20 & -1508 & 0.117 & 223 \\
\hline 0.60 & -1534 & 0.135 & 192 \\
\hline 1.00 & -1561 & 0.178 & 146 \\
\hline 2.00 & -1564 & 0.400 & 65 \\
\hline
\end{tabular}

Polarization curves of selected samples are presented in (Fig. 1). The tests proved that with increase of $\mathrm{NaCl}$ solution concentration, corrosion properties of the alloy deteriorate. Decrease of corrosion potential and polarization resistance of the alloy were observed, as was increase of corrosion current density.

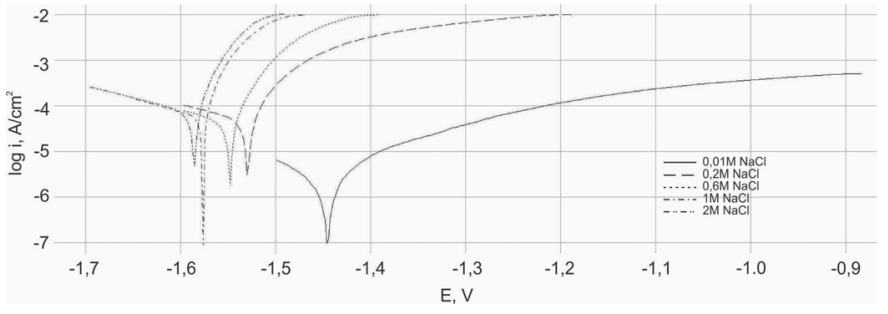

Fig. 1. Polarisation curves

Table 2 presents results of immersion test.

TABLE 2

Results of immersion test

\begin{tabular}{|c|c|c|c|}
\hline \hline \multirow{2}{*}{$\begin{array}{c}\text { Concentration NaCl, } \\
\mathbf{M}\end{array}$} & \multicolumn{3}{|c|}{ Corrosion rate $\mathbf{~}, \mathbf{~ m g} /\left(\mathrm{cm}^{\mathbf{2}} \mathbf{d a y}\right)$} \\
\cline { 2 - 4 } & $\mathbf{1}$ day & $\mathbf{3}$ days & $\mathbf{6}$ days \\
\hline 0.01 & 0.850 & 0.565 & 0.171 \\
\hline 0.60 & 4.005 & 0.972 & 1.021 \\
\hline 2.00 & 4.025 & 2.287 & 2.360 \\
\hline
\end{tabular}

Corrosion rate in the immersion test is determined on the ground of the (Eq. 1):

$$
V=\left(m_{0}-m_{1}\right) / S t,
$$

where: $V$-corrosion rate, $\mathrm{mg} /\left(\mathrm{cm}^{2}\right.$ day $), m_{0}$ - sample initial mass, $m_{1}$ - sample mass after immersion test and removal of corrosion products, $S$ - sample area, $t$ - exposure time.

Immersion tests results enabled to determine that corrosion rate increases with increase of $\mathrm{NaCl}$ solution concentration. The tests also proved that the longer the time of exposure in chloride ions environment, the lesser the corrosion rate is.

Following the exposure of samples in $\mathrm{NaCl}$ solution, microscopic tests were performed whose purpose was to evaluate the surface of the alloy. On the ground of tests performed with application of stereoscopic microscope it was proved that irrespective of solution concentration and time of exposure, changes due to corrosion are visible on the surface of the alloy. For most samples there are prominent areas affected with nonuniform corrosion. Presence of pitting corrosion was observed. For lower concentrations, more non-corroded areas can be seen. Observation of samples immersed in solution with the highest concentration, i.e. 2.0 $\mathrm{M}$ and the longest exposure prove that complete dissolution of sample fragment took place. Figs. 2-4 present results of tests performed on stereoscopic microscope.

After exposure of the alloy of magnesium and lithium for 1 and 6 days, tests were performed on scanning microscope. Test results presented in (Figs. 5-6) confirm the conclusions from observations made with stereoscopic microscope. Intensive course of corrosion process is visible, and that intensity increases with the increase of concentration of the solution and increase of exposure time. Numerous corrosion pits and cracks have been visualised. For majority of samples corrosion is nonuniform. 

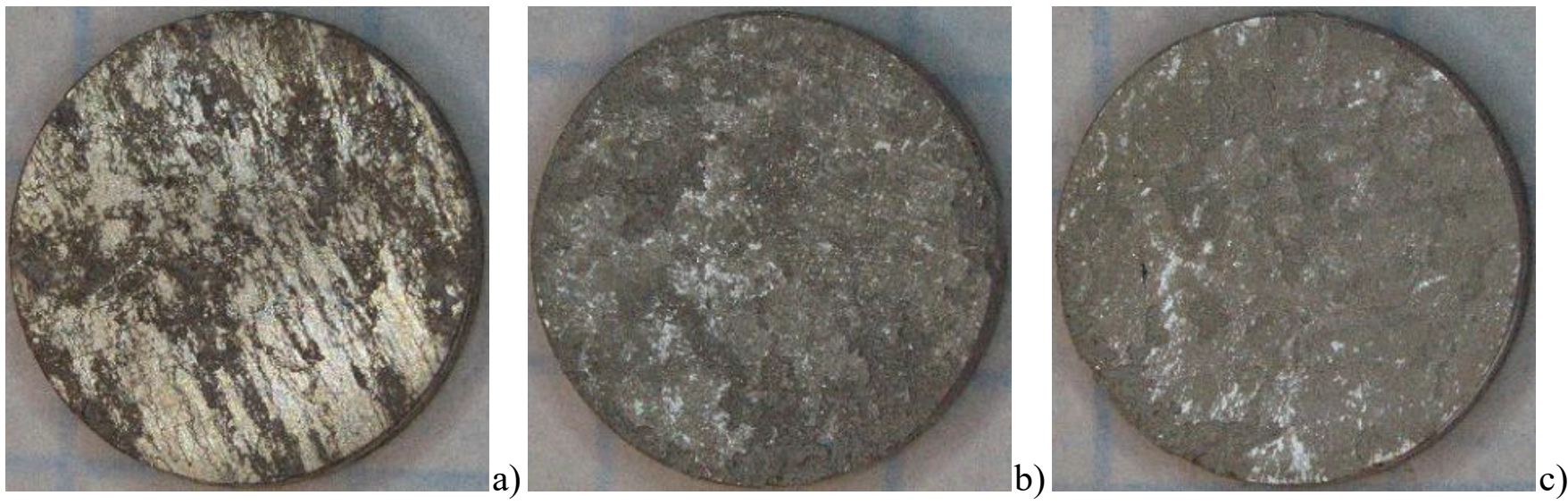

Fig. 2. Surface of samples after immersion tests performed during $24 \mathrm{~h}$ in $\mathrm{NaCl}$ solution with concentration of: a) $0.01 \mathrm{M}, \mathrm{b}) 0.6 \mathrm{M}$, c) $2.0 \mathrm{M}$
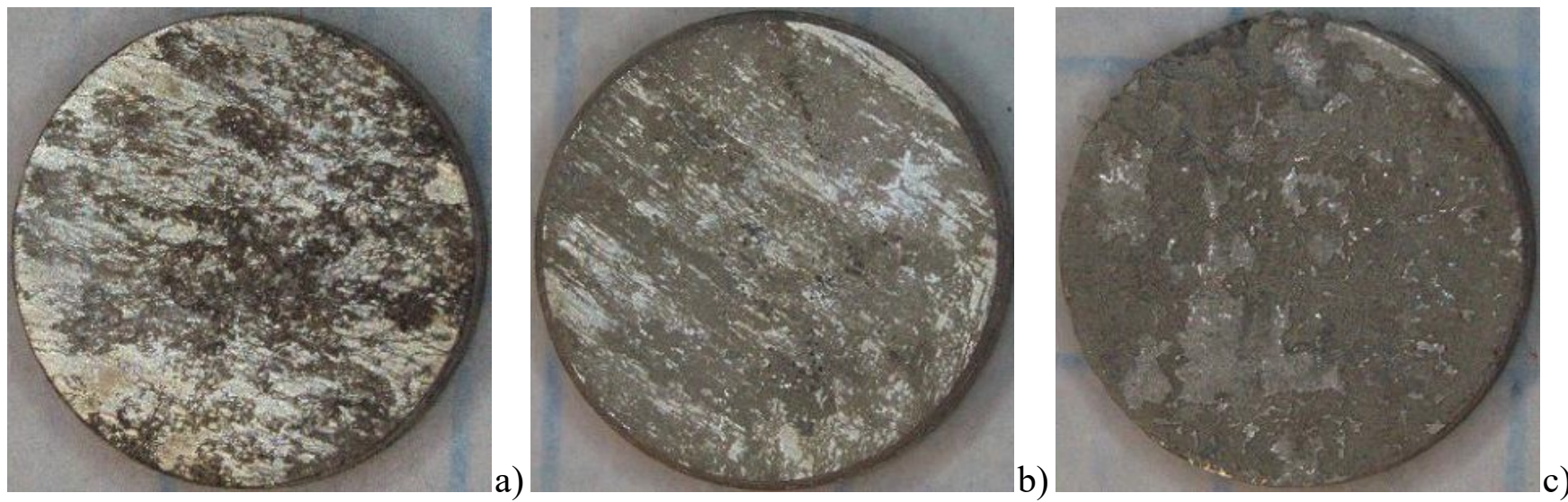

Fig. 3. Surface of samples after immersion tests performed during 3 days in $\mathrm{NaCl}$ solution with concentration of: a) $0.01 \mathrm{M}$, b) $0.6 \mathrm{M}$, c) $2.0 \mathrm{M}$
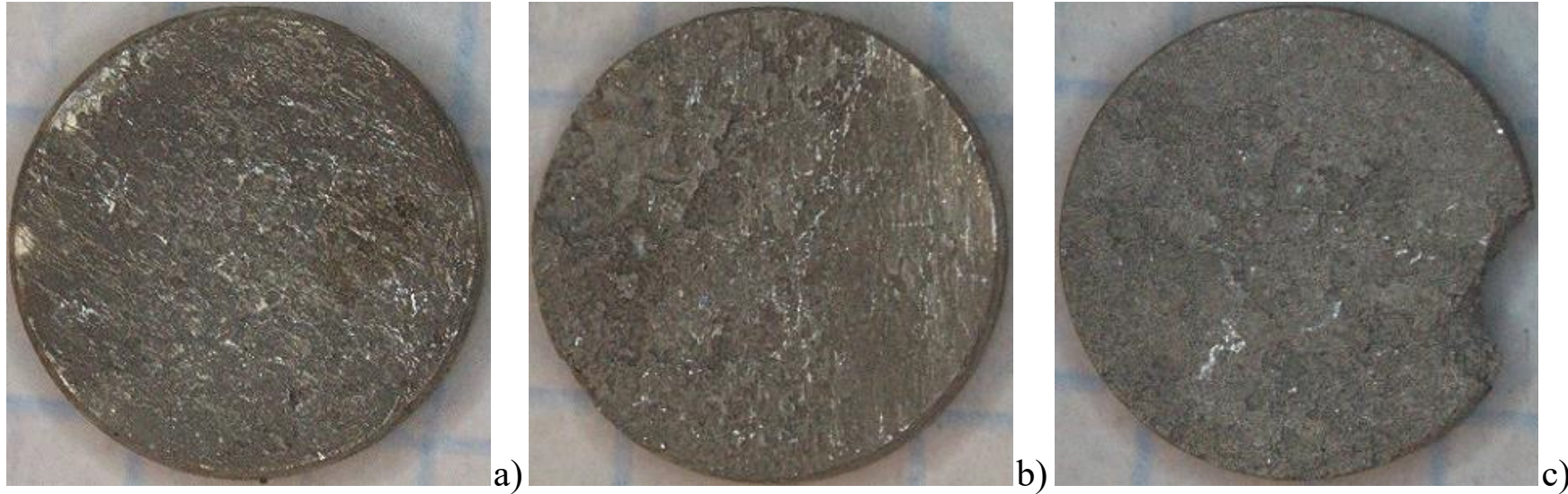

Fig. 4. Surface of samples after immersion tests performed during 6 days in $\mathrm{NaCl}$ solution with concentration of: a) $0.01 \mathrm{M}$, b) $0.6 \mathrm{M}$, c) $2.0 \mathrm{M}$

\section{Summary}

Favourable mechanical properties and low density of magnesium alloys are the reasons why magnesium alloys can be used in many branches of industry. Decrease of the mass of alloys, and therefore structures made of them (which is the goal of aircraft and automobile industries) is caused by lithium additive. Due to high application potential, magnesium alloys with lithium additive, subject to plastic forming, are currently in the phase of advanced tests. An obstacle for alloys application is their low resistance to electrochemical corrosion. Environments containing chloride ions are dangerous for magnesium alloys and lithium - their presence accelerates corrosion in inert water solutions and corrosion rate increases in such environment with increasing concentration of ions.

Potentiodynamic tests showed that magnesium alloy AZ31 with $4.5 \% \mathrm{Li}$ additive is prone to pitting corrosion in chloride environment. It was proved that corrosion properties decrease 

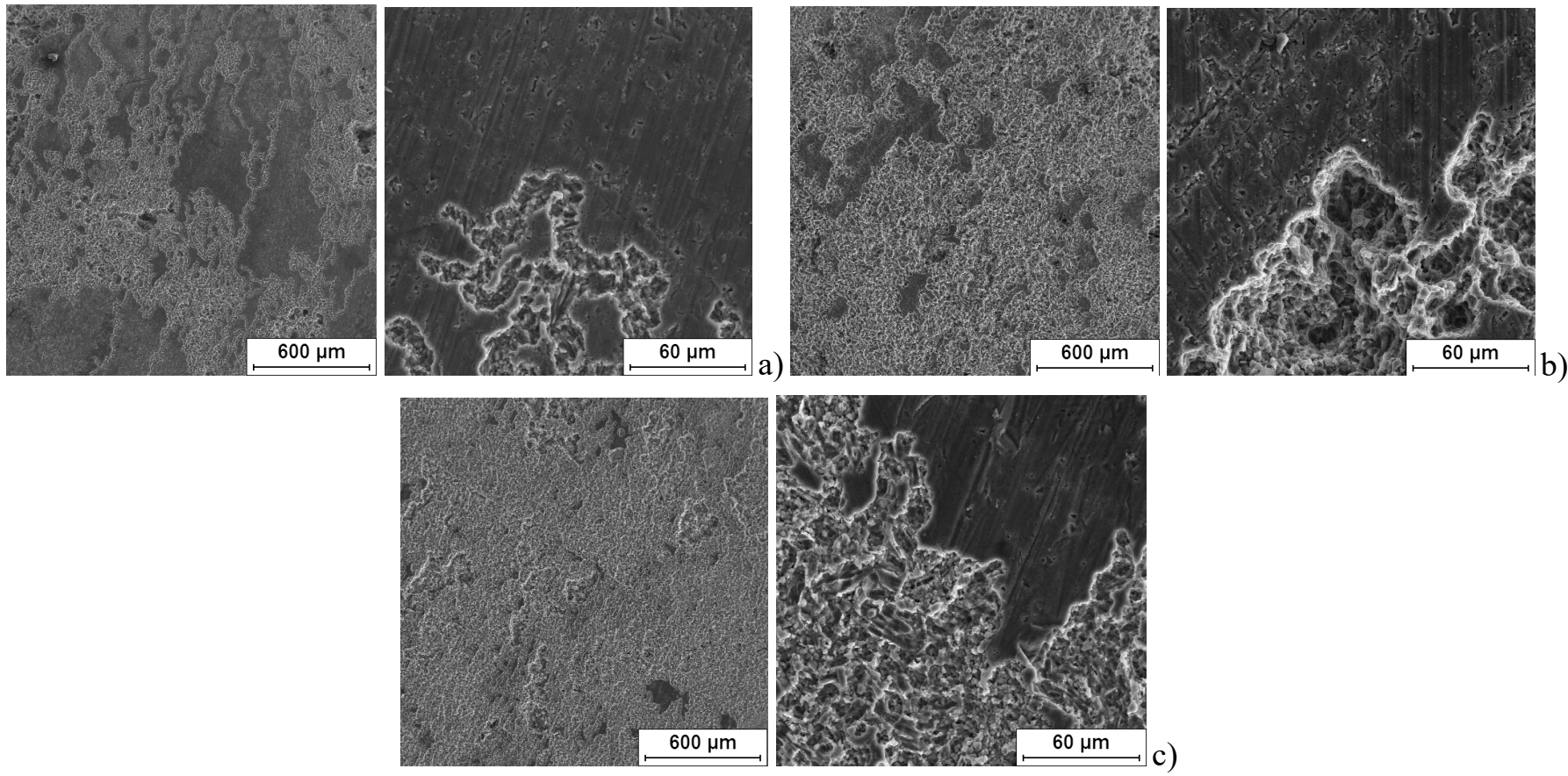

Fig. 5. Surface of samples after immersion tests performed during 1 day in $\mathrm{NaCl}$ solution with concentration of: a) $0.01 \mathrm{M}$, b) $0.6 \mathrm{M}$, c) $2.0 \mathrm{M}$
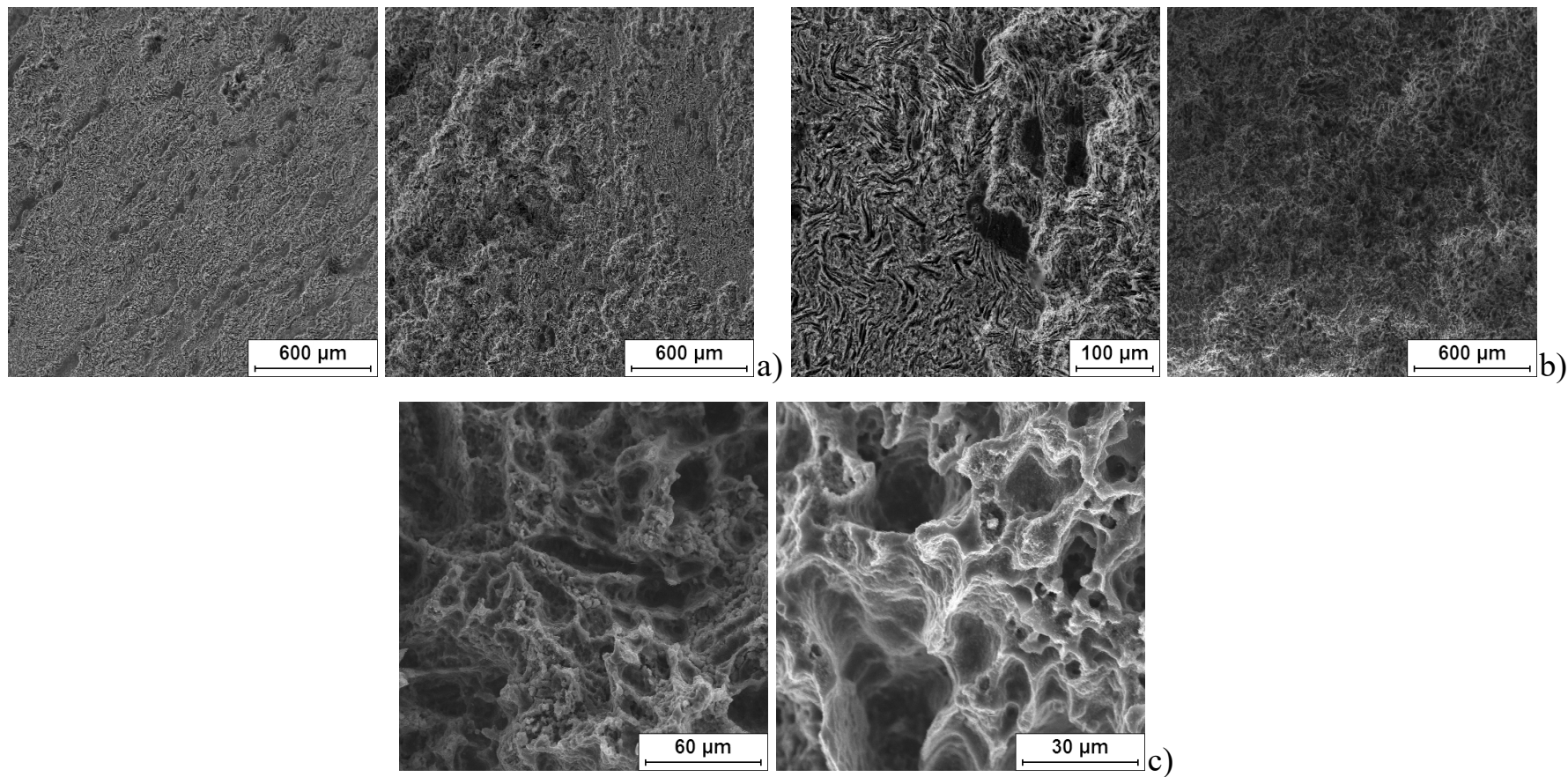

Fig. 6. Surface of samples after immersion tests performed during 6 days in $\mathrm{NaCl}$ solution with concentration of: a) $0.01 \mathrm{M}, \mathrm{b}$ ) $0.6 \mathrm{M}$, c) $2.0 \mathrm{M}$

with the increase of $\mathrm{NaCl}$ solution concentration. Metallographic tests showed that for all concentrations and time of exposure, alloy samples corroded under destructive impact of electrolyte environment. The higher $\mathrm{NaCl}$ solution concentration was, the deeper and larger pits could be observed on the surface of the alloy. For highest concentration $-2 \mathrm{M} \mathrm{NaCl}$ - even digestion of the sample took place.

Due to high susceptibility of extruded alloy of magnesium with lithium to electrochemical corrosion, it is recommended to apply coatings protecting the material from corrosive impact of aggressive environment. Then, due to low density and increased formability in plastic forming, those alloys can be used in production of constructional elements.

\section{Acknowledgements}

This paper was created with the financial support of Association of Graduates of the Faculty of Metallurgy and Materials Engineering of Silesian University of Technology, Poland. 


\section{REFERENCES}

[1] M.M. Avedesian, H. Baker (Eds.). ASM Specialty Handbook: Magnesium and Magnesium Alloys, 1999 ASM International, Materials Park, OH, USA.

[2] M. Saternus, Rudy Metale 53, 337 (2008).

[3] R. Kawalla, G. Lehmann, M. Ullmann, H.P. Voght, Arch. Civ. Mech. Eng. 8, 93 (2008).

[4] Z. Yang, J.P. Li, J.X.Zhang, G.W. Lorimer, J. Robson, Acta Metall. Sin. 21, 313 (2008).

[5] T. Rzychoń, B. Adamczyk-Cieślak, A. Kiełbus, J. Mizera, Materialwissensch. Werkstofftech. 43, 421 (2012).

[6] P. Lichý, J. Beňo, P. Lackova, M. Morys, Metalurgija 53, 303 (2014).

[7] P. Lichý, J. Beňo, M. Cagala, J. Hampl, Metalurgija 52, 473 (2013).

[8] T. Rzychoń, A. Kiełbus, L. Lityńska-Dobrzyńska, Mater. Charact. 83, 21 (2013).

[9] A. Olszówka-Myalska, J. Myalski, J. Chrapoński, Int. J. Mater. Res. 106, 741 (2015).

[10] A. Olszówka-Myalska, J. Myalski, Solid State Phenomena 229, 115 (2015)

[11] A. Olszówka-Myalska, J. Mater. Eng. Perform. 25, 3091 (2016).

[12] R. Kawalla, Magnez i stopy magnezu (w pracy zbiorowej pod redakcją E. Hadasika Przetwórstwo metali. Plastyczność a struktura) Wydawnictwo Politechniki Śląskiej, Gliwice 2006.

[13] T. Tański, P. Snopiński, W. Pakieła, W. Borek, K. Prusik, S. Rusz, Arch. Civ. Mech. Eng. 16, 325 (2016).

[14] M. Ullmann, F. Berge, K. Neh, R. Kawalla, Metalurgija 54, 711 (2015).

[15] S. Ziółkiewicz, M. Gąsiorkiewicz, P. Wesołowska, S. Szczepanik, R. Szyndler, Obr. Plast. Metali 23, 57 (2012).
[16] Y. Xu-yue, H. Miura, T. Sakai, Trans. Nonferrous Met. Soc. China 17, 1139 (2007)

[17] A. Gontarz, Z. Pater, K. Drozdowski, Metalurgija 52, 359 (2013).

[18] A. Białobrzeski, K. Saja, K. Hubner, Arch. Foundry Eng. 7, 11 (2007).

[19] A. Białobrzeski, K. Saja, Arch. Foundry Eng. 11, 21 (2011).

[20] C. Zhang, X. Huang, M. Zhang, L. Gao, R. Wu, Mater. Lett. 62, 2181 (2008).

[21] G.L. Maker, J. Kruger, Int. Mater. Rev. 38, 138 (1993).

[22] R.-C. Zeng, J. Zhang, W.-J. Huang, W. Dietzel, K.U. Kainer, C. Blawert, W. Ke, Trans. Nonferrous Met. Soc. China 16. 763 (2006).

[23] J. Przondziono, W. Walke, J. Szala, E. Hadasik, J. Wieczorek, IOP Conference Series, Materials Science and Engineering 22, 012017 (2011).

[24] P.W. Chu, E.A. Marquis, Corr. Sci. 101, 94 (2015).

[25] R. Przeliorz, J. Piątkowski, Metalurgija 55, 429 (2016).

[26] Y. Yang, W.-L. Dai, X.-B. Li, P.-J. Ni, R.-D. Qiao, Chinese J. Nonferrous Metals 25, 2666 (2015).

[27] J. Przondziono, W. Walke, A. Szuła, E. Hadasik, J. Szala, J. Wieczorek, Metalurgija 50, 239 (2011).

[28] M. Kappes, M. Iannuzzi, R.M. Carranza, Corrosion 70, 667 (2014).

[29] J. Przondziono, E. Hadasik, W. Walke, J. Szala, J.K. Michalska, J. Wieczorek, Mater. Technol. 49, 275 (2015).

[30] G. Oktay, M. Ürgen, Corros. Eng. Sci. Techn. 50, 380 (2015).

[31] Y. Shangguan, P. Wan, L. Tan, X. Fan, L. Qin, K. Yang, J. Colloid Interface Sci. 481, 1 (2016).

[32] L. Wang, T. Shinohara, B.-P. Zhang, J. Solid State Electrochem. 14, 1897 (2010). 